\title{
Investigation Of Fiber Length Change In Different Stages Of Ring Spinning Process
}

\author{
Md. Rubel Khan, Assistant Professor \\ Department of Yarn Engineering, \\ Bangladesh University of Textiles, Bangladesh \\ Md. Mamunur Rashid, Assistant Professor \\ Department of Industrial and Production Engineering, \\ Bangladesh University of Textiles, Bangladesh \\ Sharif Ahmed, Assistant Professor \\ Department of Yarn Engineering, \\ Bangladesh University of Textiles, Bangladesh \\ Md Ehsanur Rashid, Junior Executive \\ Yarn Dyeing marketing, \\ M.N. Dyeing, Printing \& Washing Mills Ltd \\ Gazipur, Bangladesh \\ Raihan UI Haque, Junior Executive \\ Fabric Dyeing marketing, \\ M.N. Dyeing, Printing \& Washing Mills Ltd. \\ Gazipur, Bangladesh
}

Doi:10.19044/esj.2021.v17n25p66

Submitted: 01 July 2021

Accepted: 18 July 2021

Published: 31 July 2021
Copyright 2021 Author(s)

Under Creative Commons BY-NC-ND

4.0 OPEN ACCESS

Cite As:

Khan R., Rashid M., Ahmed Sh., Rashid E. \& Ul Haque R. (2021). Investigation Of Fiber Length Change In Different Stages Of Ring Spinning Proces. European Scientific Journal, ESJ, 17(25), 66.

https://doi.org/10.19044/esj.2021.v17n25p66

\begin{abstract}
Fiber length is one of the major fiber properties that influence yarn strength, evenness, product handle, product luster, and yarn hairiness. To assure yarn quality, fiber passes through a number of machinery during the spinning process, where it is subjected to various sorts of action that modifies the fiber length. As different process parameters are chosen based on fiber length, fiber length analysis throughout the spinning process will benefit in the
\end{abstract}


adjustment of machine parameters to produce better quality yarn. This study will reveal the chronological change in average fiber length at different stages of the carded ring spinning process, as well as a correlation analysis of length change among different phases, using correlation and regression methods. For five distinct mixing samples, raw cotton, card mat, carded sliver, breaker drawn sliver, finisher drawn sliver, roving, and yarn (pneumafil) were examined at each stage from raw cotton to ring frame. Then, using USTER AFIS PRO, all of the samples were numerically evaluated and statistically analyzed using Microsoft Excel 2016. A positive correlation between fiber length changes at several phases was observed in the experiment, with average fiber length increasing in carding, breaker drawing, finisher drawing, and simplex but decreasing in card mat and ring.

Keywords: Fiber Length, Ring Spinning, Yarn Strength, Fiber Breakage

\section{Introduction}

Fiber properties are known to be the significant indicators of yarn quality, with length, fineness, strength, maturity, and grade all contributing materially, albeit in varying degrees (Fiori, 1956; Fiori \& Brown, 1951; Gregory, 1953; W. P. Virgin and Helmut Wakeham, 1956). Fiber length is one of the most crucial fiber characteristics (Cai, 2013; Kuang \& Yu, 2015; Lin, 2012; Morais, 2020; Parsi, 2016), influencing the spinning limit (Faulkner, 2012), yarn strength (Fiori, 1954; Naylor, 2014; Ramey , 1977), yarn evenness and product handle (Frydrych, 1995; Ibrahim, 2018; Moon Won Suh, 1976), yarn hairiness (Barella \& Manich, 2002; Informa, 2009; Matsuo, 2019; Pillay, 1964; Viswanathan , 1989), process performance, and spinning efficiency (Waters, 1966). However, the length of the fiber changes during the spinning process as it is subjected to various mechanical actions in various machines (Byatt, W. J., and Elting, 1958; Byatt, 1961; Carnaby, 1984; Goren, 1968; Lee, 1968; RA Pittman and JD Tallant, 1990; Shapiro, 1964; Sung Won, 1967; Tallant, 1966; Tallant \& Pittman, 1968) that affect the yarn quality as well as the end product generated from the yarn. An examination was carried out in this study to assess fiber length change throughout various stages of ring spinning. Different samples were taken for this purpose from each stage of the cotton fiber mixing procedure in the card spinning process. The change in fiber length in each stage of spinning was studied using AFIS length measurement (Bragg \& Shofner, 1993). The extent of the fiber length change-increment or decrement-was then determined, and the reasonable explanations of the alterations are described. 


\section{Literature Review}

Changes in fiber length at each stage of the spinning process are significant seeing as fiber length has a direct impact on yarn properties and the end product. Many researchers have tried to figure out why fiber length changes and have proposed numerous models to solve the problem. Previously, various researchers (Goren, 1968; Sung Won, 1967; Tallant, 1966) discussed fiber breakage and attempted to explain it using various models. After a few years, Robert and his coworkers investigated the relationship between cotton cleanliness and fiber breakage. They also demonstrated a method for measuring, tracking, and analyzing fiber breakage during the process (Robert, 2000; Robert \& Blanchard, 1997). M. Krifa devised a finite mixture distribution model to parameterize the length distribution of cotton fibers in 2008. (Krifa, 2008). V. A. Wakankar and colleagues addressed several mechanisms responsible for different hook (trailing and leading) formation at the cylinder-doffer junction(Wakankar, 1961). According to S. Ahmad, friction and cohesion forces remove this hook during the drawing process (Ahmad, 2012). In the 1960s, John D. Tallant and associates examined The Effect of Short Fibers in Cotton on Processing Efficiency and Product Quality (Tallant, 1961b, 1961a; Tallant \& Landstreet, 1960), and more recently, M. Krifa studied the bimodal and unimodal structure of fiber length distribution and its impact on fiber length distribution (Krifa, 2006). W. Zurek, M. Greszta, and I. Frydrych experimented with the theoretical consideration of fiber length and diameter changes in the process of yarn manufacturing in 1999. Based on AFIS results, they carried out their work, emphasizing on the combing process and noil extraction based assumptions (Zurek, 1999). In 2002, Zeidman and Sawhney examined cotton fiber length distribution and its effect on yarn strength to gain a better understanding of the length-strength relationship (Sawhney \& Zeidman, 2002). They also attempted to simulate the strength of fiber assemblies in yarn. In 2007, G. Yan and $\mathrm{C}$. Yu attempted to explain the comprehensive influence of fiber length and fineness on yarn strength, and they offered a plausible method to estimate the critical length represented by Zeidman (Yan \& Yu, 2007). W. B. Faulkner and associates conducted a study on the relationships between ring-spun yarn quality and fiber in 2012 and discovered that yarn work-to-break was highly correlated with fiber bundle elongation(Faulkner, 2012). In the same year, Q. Lin and colleagues showed a correlation between fiber length statistics and length measurement and used a finite mixture model to develop a probability density function for fiber length (Lin, 2012). Y. Cai investigated the impacts of multiple length parameters and their combinations on yarn properties in 2013. (Cai, 2013). In 2014, K. Kuang and C Yu used the Finite Mixture Model to generate the fiber length probability density function of different cotton samples and compared it to other models. They discovered that test data could 
fit very well within a 0.0045 error margin (Kuang \& Yu, 2015). R. D. Parsi and colleagues examined the relationships between ring-spun yarn quality and fiber length in 2016 (Parsi, 2016). They used the AFIS tester for fiber testing and the UT3 tester for yarn testing. In 2020, J. Morais proposed a method to improve cotton fiber length measurement for laboratory analysis (Morais, 2020). The approach successfully lowers the discrepancies in fiber length parameters between industry-scale and laboratory-scale ginning, according to the researchers.

\section{Methodology}

Five different mixing samples (MT1, MT2, MT3, MT4, and MT5) were collected from each phase of the card spinning process. The length of cotton fiber was then measured in Card Mat, Carding, Breaker Drawframe, Finisher Drawframe, Simplex, and Ring Frame machines using the Advance Fiber Information System (AFIS).

\section{Raw Material Selection}

The research experiment was carried out in the running condition of Zaber Spinning Mills Ltd. Five mixing types were taken into account for fiber length analysis, each of which is pure cotton from different origins. Table 1 shows the five mixing ratios.

Table 1. Different mixing types with fiber origin and their percentage

\begin{tabular}{|c|c|}
\hline Mixing Type & Fiber Origin and Percentage \\
\hline Mixing type-1 (MT1) & Ivory coast (35\%), Benin (30\%), Mali (35\%) \\
\hline Mixing type-2 (MT2) & $\begin{array}{c}\text { Ivory Coast (70\%), Zambian (20\%), Cameroon (5\%), Sanker- } \\
06 \text { (5\%) }\end{array}$ \\
\hline Mixing type-3 (MT3) & Ivory Coast (45\%), Burkina Faso (20\%), Mali (35\%) \\
\hline Mixing type-4 (MT4) & Ivory Coast (30\%), Burkina Faso (35\%), Mali (35\%) \\
\hline Mixing type-5 (MT5) & Ivory Coast (25\%), Burkina Faso (40\%), Mali (35\%) \\
\hline
\end{tabular}

\section{Machinery used}

Machine names, models, and parameters, as well as their values are provided in Table 2.

Table 2. Machine parameters used in the card spinning process

\begin{tabular}{|c|c|c|c|c|c|}
\hline Machine & Parameter & Value & Machine & Parameter & Value \\
\hline \multirow[t]{4}{*}{$\begin{array}{l}\text { Blow Room } \\
\text { (Trutzschler) }\end{array}$} & BDT & $\begin{array}{l}\text { Advance } \\
\text { d: } 3 m m\end{array}$ & \multirow{4}{*}{$\begin{array}{l}\text { Finisher } \\
\text { Draw } \\
\text { Frame } \\
\text { (DX-8LT, } \\
\text { Toyota) }\end{array}$} & Del. Hank & $0.120 \mathrm{Ne}$ \\
\hline & \multirow[t]{2}{*}{ CL-P } & $\begin{array}{l}\text { Roller } \\
\text { rpm: } 800\end{array}$ & & $\begin{array}{l}\text { Del. Speed } \\
(\mathrm{m} / \mathrm{min})\end{array}$ & 400 \\
\hline & & $\begin{array}{l}\text { Wing } \\
\text { Setting = } \\
3^{0}\end{array}$ & & $\begin{array}{l}\text { Roller } \\
\text { Gauge }\end{array}$ & $39 * 40 * 44 \mathrm{~mm}$ \\
\hline & CL-C3 & $\begin{array}{l}\text { Roller } \\
\text { rpm: }\end{array}$ & & Trumpet & $3.8 \mathrm{~mm}$ \\
\hline
\end{tabular}




\begin{tabular}{|c|c|c|c|c|c|}
\hline & & $\begin{array}{l}1100, \\
1800, \\
2300 \\
\end{array}$ & & & \\
\hline & & $\begin{array}{l}\text { Wing }=10 \\
0,15^{0}, 25^{0}\end{array}$ & & Draft & 8.25 \\
\hline \multirow[t]{6}{*}{$\begin{array}{l}\text { Carding (TC- } \\
\text { 06) }\end{array}$} & $\begin{array}{l}\text { Sliver } \\
\text { Grain/yds }\end{array}$ & 75.75 & & Back Draft & 1.25 \\
\hline & Del. Hank & $0.110 \mathrm{Ne}$ & \multirow{8}{*}{$\begin{array}{l}\text { Simplex } \\
\text { (Toyoda- } \\
\text { FL-100) }\end{array}$} & Del. Hank & $0.90 \mathrm{Ne}$ \\
\hline & $\begin{array}{l}\text { Delivery } \\
\text { Speed }\end{array}$ & $\begin{array}{l}210 \mathrm{~m} / \mathrm{mi} \\
\mathrm{n} \\
(62 \mathrm{Kg} / \mathrm{h})\end{array}$ & & TPI / TM & $1.13 / 1.119$ \\
\hline & Flat Speed & $310 \mathrm{~mm}$ & & Flyer speed & $1050 \mathrm{rpm}$ \\
\hline & $\begin{array}{l}\text { Cylinder } \\
\text { Speed }\end{array}$ & $560 \mathrm{~mm}$ & & Spacer & Green (6.5) \\
\hline & Wing Setting & $5^{0}$ & & Roller gauge & $=9 * 21 * 20.5 \mathrm{~mm}$ \\
\hline \multirow{8}{*}{$\begin{array}{l}\text { Breaker } \\
\text { Draw Frame } \\
\text { (D X-7AH, } \\
\text { Toyota) }\end{array}$} & $\begin{array}{l}\text { Sliver } \\
\text { (Grain/yds) }\end{array}$ & 69.44 & & Break draft & 1.21 \\
\hline & Del. Hank & $0.120 \mathrm{Ne}$ & & Total draft & 7.72 \\
\hline & $\begin{array}{l}\text { Del. Speed } \\
(\mathrm{m} / \mathrm{min})\end{array}$ & 450 & & $\begin{array}{l}\text { DCP and } \\
\text { TCP }\end{array}$ & 44 and 41 \\
\hline & Doubling & 07 & \multirow{5}{*}{$\begin{array}{l}\text { Ring } \\
\text { Frame }\end{array}$} & Count & $30 \mathrm{Ne}$ \\
\hline & Roller Gauge & $\begin{array}{l}=39 * 43 \\
\mathrm{~mm}\end{array}$ & & TPI / TM & $22.09 / 4.0$ \\
\hline & Draft & 7.30 & & $\begin{array}{l}\text { Spindle } \\
\text { speed }\end{array}$ & $16200 \mathrm{rpm}$ \\
\hline & Back Draft & 1.35 & & $\begin{array}{l}\text { Traveller } \\
\text { No. }\end{array}$ & 4/0(Bracker) \\
\hline & & & & $\begin{array}{l}\text { Roller } \\
\text { Gauge }\end{array}$ & $44 * 60 \mathrm{~mm}$ \\
\hline
\end{tabular}

\section{Sample collection and test}

Raw cotton, card mat, carded sliver, breaker drawn sliver, finisher drawn sliver, roving, and yarn (pneumafil) were sampled at each stage from raw cotton to ring frame. Finally, all of the samples were tested numerically by USTER AFIS PRO and statistically analyzed using Microsoft Excel 2016.

\section{Result and Discussion}

Table 3 and Figures 1, 2, 4, and 5 display that fiber length was reduced in the blow room for MT1, MT2, MT4, and MT5. Fibers were beaten at various points in the blow room line, primarily in the coarse cleaner (CLP) and fine cleaner (CLC-3). They got broken because of this beating action, which results in a reduction in the average fiber length in the card mat. However, for MT3, the fiber length was increased because of the natural variability in raw material.

Table 3. Change in fiber length for different mixing types in different processing stages. 


\begin{tabular}{|c|c|c|c|c|c|c|c|c|c|c|}
\hline $\begin{array}{c}\text { Processing } \\
\text { Stage }\end{array}$ & \multicolumn{10}{|c|}{$\begin{array}{c}\text { Length (L) (In mm) } \\
\text { Change in Length }(\Delta \mathbf{L})(\mathbf{I n} \text { mm) }\end{array}$} \\
\cline { 2 - 12 } & $\begin{array}{c}\text { MT1 } \\
(\mathbf{L})\end{array}$ & $\Delta \mathbf{L}$ & $\begin{array}{c}\text { MT2 } \\
(\mathbf{L})\end{array}$ & $\Delta \mathbf{L}$ & $\begin{array}{c}\text { MT3 } \\
(\mathbf{L})\end{array}$ & $\Delta \mathbf{L}$ & $\begin{array}{c}\text { MT4 } \\
(\mathbf{L})\end{array}$ & $\Delta \mathbf{L}$ & $\begin{array}{c}\text { MT5 } \\
(\mathbf{L})\end{array}$ & $\Delta \mathbf{L}$ \\
\hline $\begin{array}{c}\text { Raw } \\
\text { cotton }\end{array}$ & 30.30 & 0 & 31.23 & 0 & 28.70 & 0 & 28.70 & 0 & 28.12 & 0 \\
\hline Card Mat & 29.60 & -0.70 & 29.48 & -1.75 & 29.40 & +0.70 & 28.30 & -0.40 & 27.90 & -0.22 \\
\hline Carding & 30.00 & +0.40 & 29.97 & +0.49 & 29.60 & +0.20 & 29.00 & +0.70 & 28.80 & +0.90 \\
\hline $\begin{array}{c}\text { Breaker } \\
\text { Drawing }\end{array}$ & 30.20 & +0.20 & 29.65 & & 29.70 & & 29.20 & +0.20 & & \\
\hline $\begin{array}{c}\text { Finisher } \\
\text { Drawing }\end{array}$ & 30.70 & +0.50 & & -0.32 & & +0.10 & & & 29.20 & +0.40 \\
\hline Simplex & 31.10 & +0.40 & 30.11 & -0.15 & 30.40 & +0.10 & 29.80 & -0.10 & 29.20 & +0.50 \\
\hline Ring & 29.90 & -1.20 & 28.18 & -1.93 & 28.90 & -1.50 & 28.80 & -1.00 & 28.00 & -1.20 \\
\hline
\end{tabular}

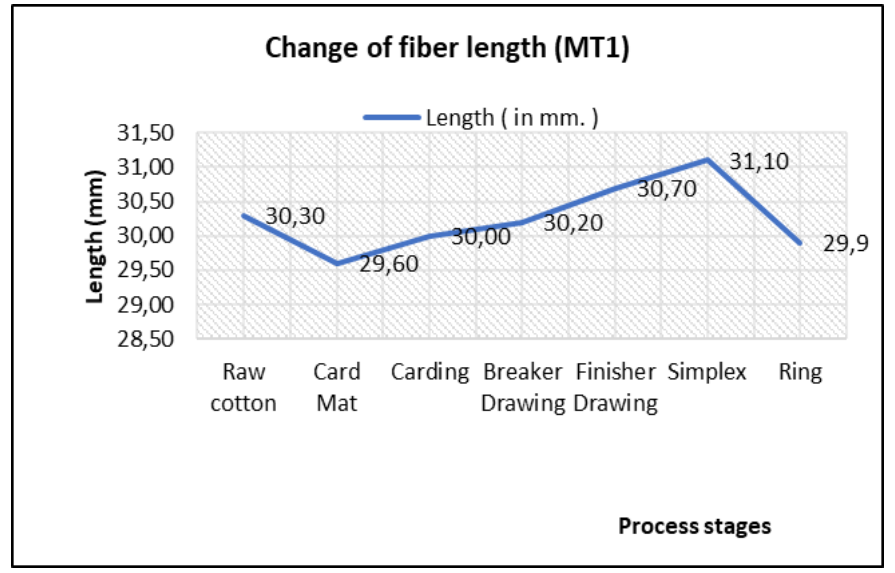

Figure 1. Change in Fiber length for MT1

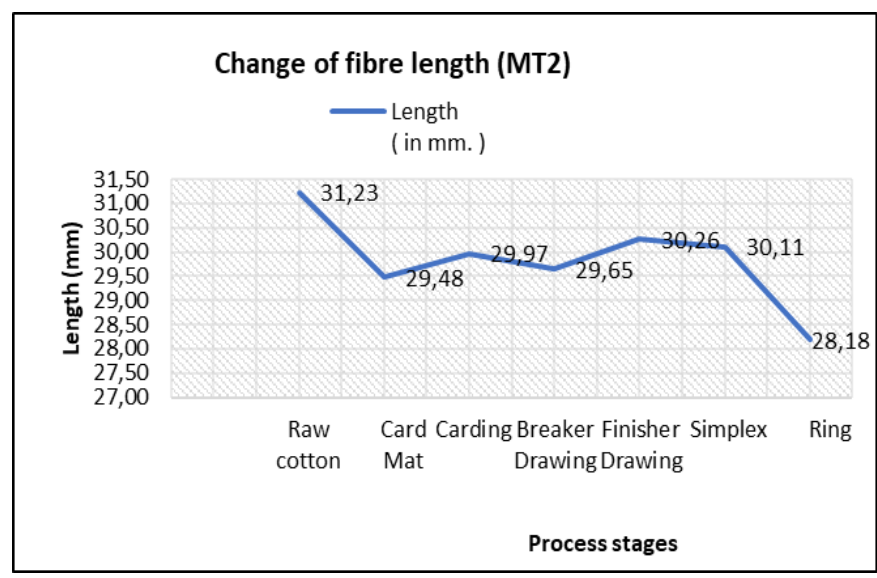

Figure 2. Change in fiber length for MT2

Table 3 and figures 1,2,3,4, and 5 display that fiber length increased during the carding process for all mixing types. Disentanglement of fiber neps, 
and short fibers were removed as strips and dropping- 1 during the carding process. For this reason, the average length of the fiber was increased. Table 3 and Figures 1, 3, 4, and 5 show that the fiber length was increased in the breaker drawing for MT1, MT3, MT4, and MT5. Drawing action is behind the removal of trailing and leading hooks in the breaker draw frame (Nield, 1953). As a result, fiber length was increased. However, an exception is seen in MT2 as a result of inherent variations in raw materials.

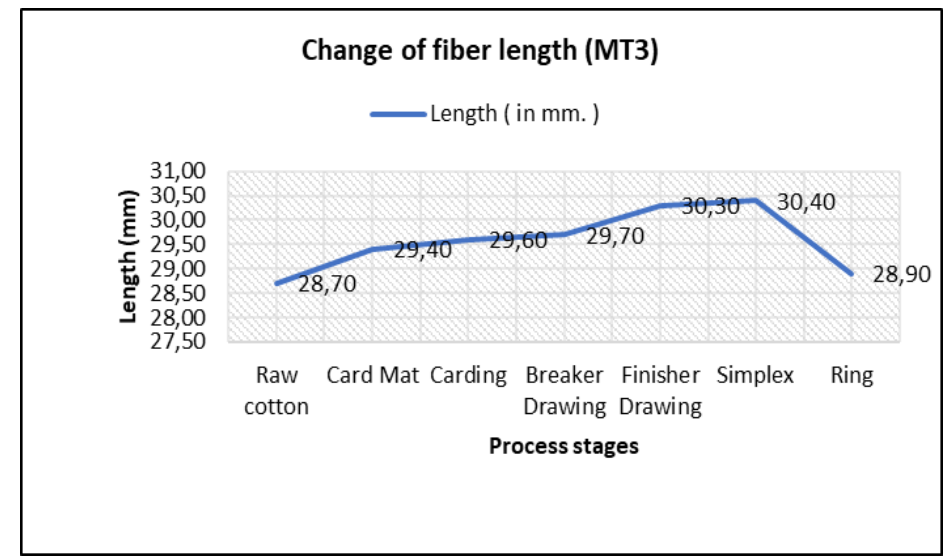

Figure 3. Change in fiber length for MT3

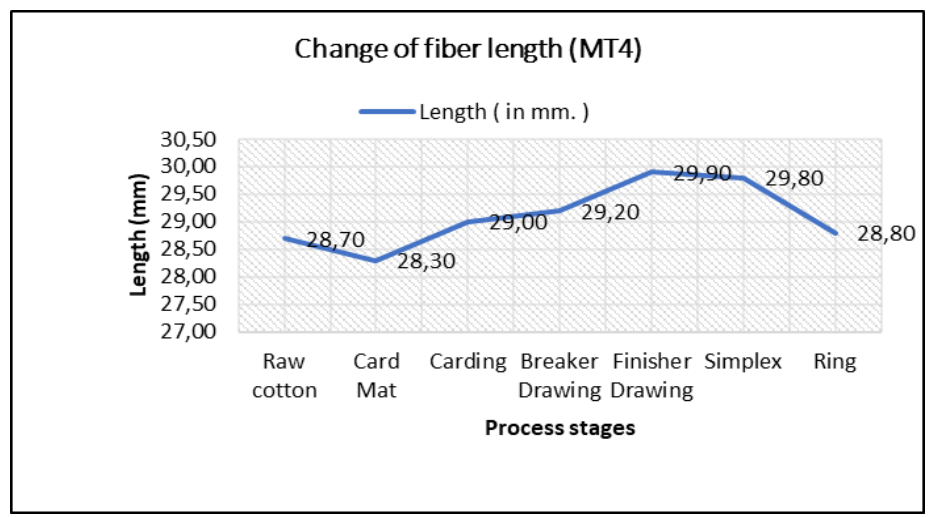

Figure 4. Change in fiber length for MT4

Fiber length was increased for finisher drawing for MT1, MT2, MT3, and MT4, as shown in table 3 and figures 1, 2, 3, and 4. Trailing and leading hooks were removed in the finisher draw frame by means of drawing action(Nield, 1953) that caused an increase in fiber length. However, Due to natural deviations in raw materials, there was an exception for MT5. Table 3 and figures 1, 3, and 5 reveal that fiber length increases in simplex for MT1, MT3, and MT5. In simplex, the trailing and leading hooks were deleted by drawing action. A waste reduction target of 0.5 percent had been set for the machine, and in this process, fly and short fibers were removed. As a result, 
fiber length was increased. Due to inherent diversity in raw materials, there were a few exceptions for MT3 and MT5. Fiber length was reduced in the ring frame for all mixing types, as shown in table 3 and figures 1,2,3,4, and 5 . In a ring frame, a higher draft was applied to manufacture yarn, which caused fibers to break and length to be shortened. In simplex, the trailing and leading hooks were deleted by drawing action. As a result, fiber length was increased. Several exceptions were seen for MT3 and MT5.

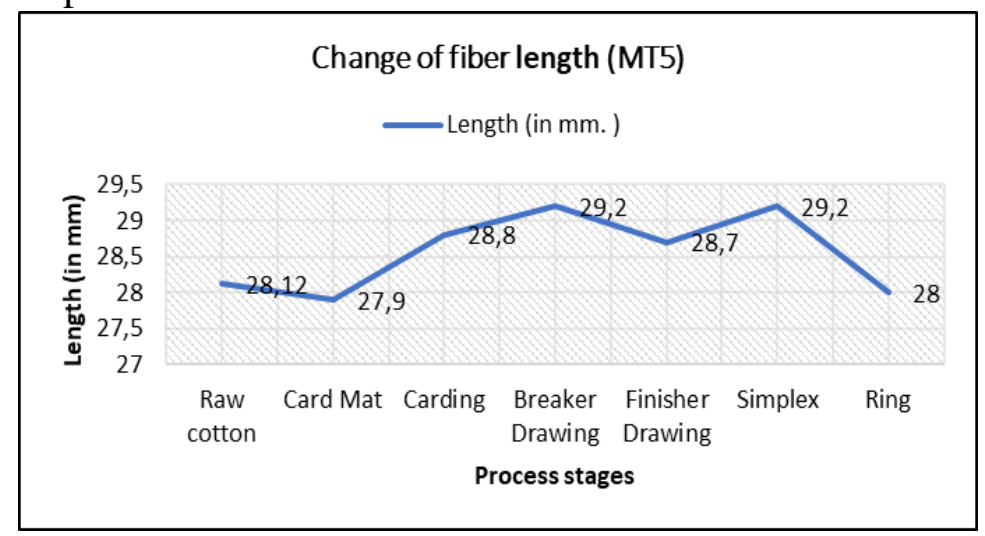

Figure 5. Change in fiber length for MT5

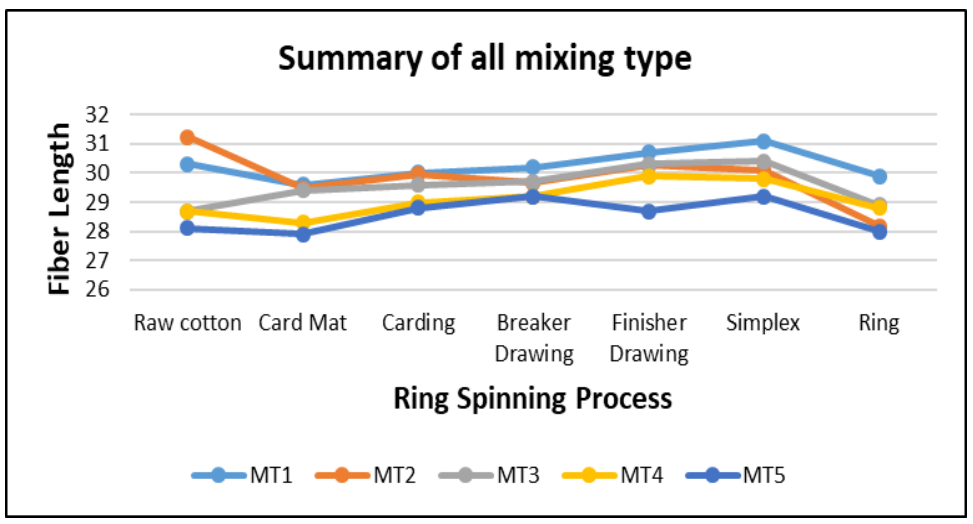

Figure 6. Summary of all mixing types for all process

A typical down-up-down pattern can be seen in figure 6. To begin, a descending trend for fiber length was noted from raw cotton to card mat. Second, a consistent upward trend in fiber length was observed from card mat to simplex. Finally, a downward pattern for fiber length is evident from simplex to ring. There are some anomalies, which are caused by inherent variations in the raw material. 


\section{Correlation analysis of fiber length change in different stages of Ring spinning process}

Correlation Analysis is a statistical approach for determining whether or not two variables or datasets have a relationship and, if so, how strong that relationship is. Visualizing the findings of a set of data on a scatter graph is the best technique to get a generalized but more instantaneous interpretation of them. Any regression coefficient $\left(\mathrm{R}^{2}\right)$ value between +0.5 and +1.0 indicates a very substantial positive correlation, implying that they both increase at the same time. A positive correlation between raw cotton and card mat is noticed in table 4 section 1 . The regression coefficient, $\mathrm{R}^{2}$, was 0.5611 , and the regression line equation was $y=15.74+0.4485 x$. Table 4 section 2 shows a positive correlation between card mat and card sliver. The regression coefficient, $\mathrm{R}^{2}$, was 0.9509 , and the regression line equation was $y=0.69 x+9.5006$. A positive correlation between carded sliver and breaker drawn sliver is noticed in table 4 section 3 . The regression coefficient was $\mathrm{R}^{2}=0.783$, and the regression line equation was $\mathrm{y}=0.667 \mathrm{x}+9.928$. A positive correlation between breaker drawn sliver and finisher drawn sliver is observed in table 4 section 4 . The regression coefficient was $R^{2}=0.6435$, and the regression line equation was $y=1.476 \mathrm{x}-13.71$. Table 4 section 5 shows a favorable relationship between finisher drawn sliver and simplex roving. The regression coefficient was $\mathrm{R}^{2}=0.8549$, and the regression line equation was $y=4.60+0.85 x$. Table 4 section 6 indicates a positive correlation between simplex roving and ring yarn. The regression coefficient was $\mathrm{R}^{2}=0.7694$, and the regression line equation was $y=0.741+0.93 x$. In all six sections, a positive correlation is detected, illustrating a positive correlation between fiber length changes at different phases.

Table 4. Correlation analysis of fiber length change in different stages.

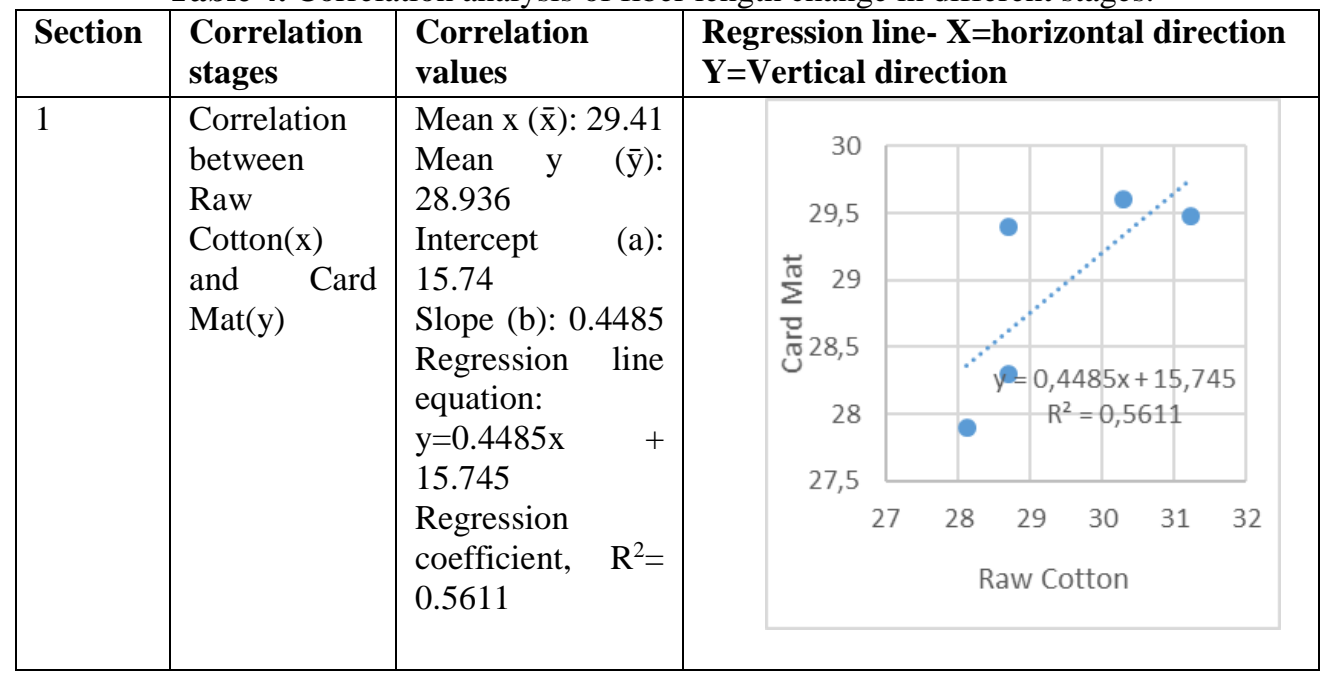




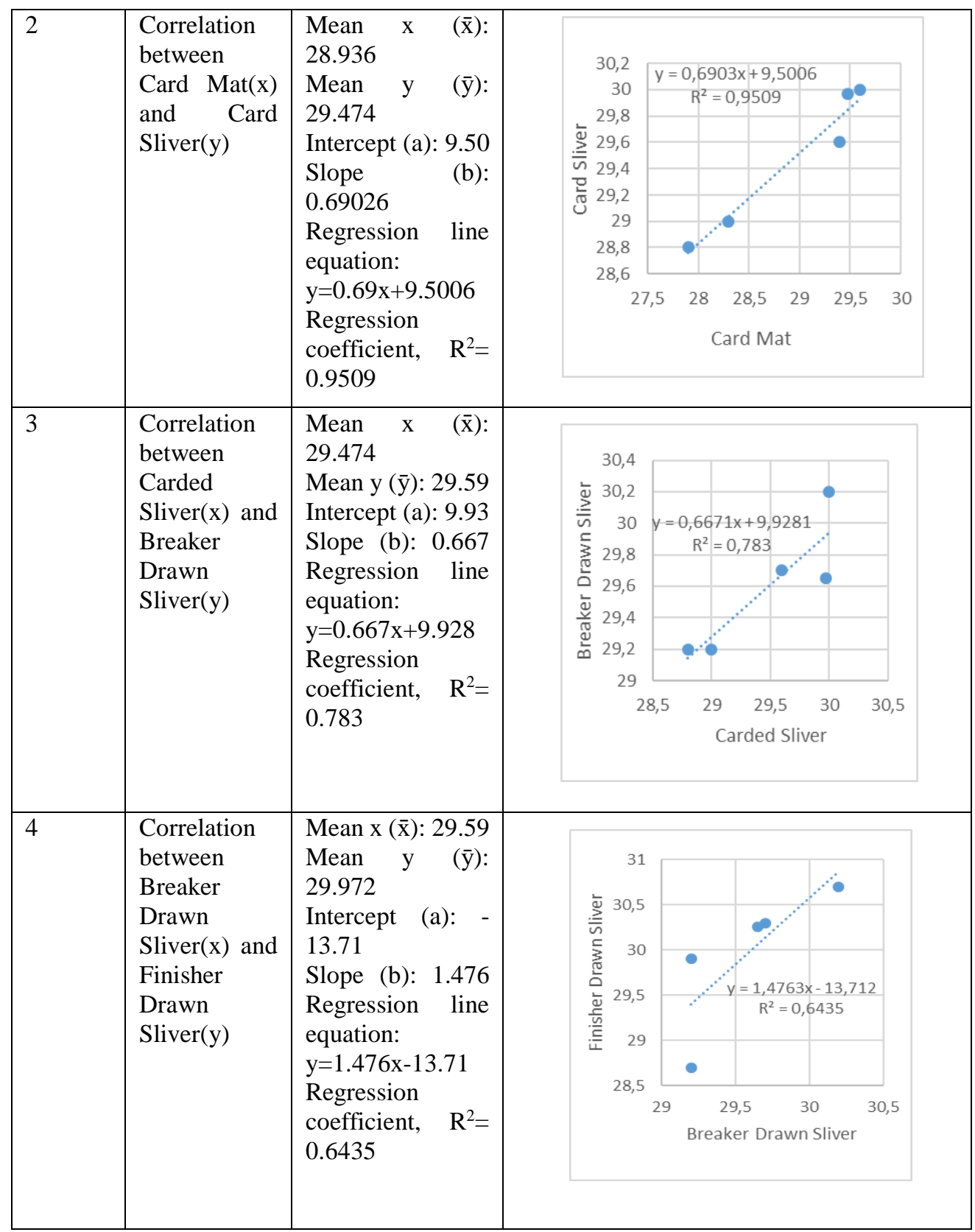




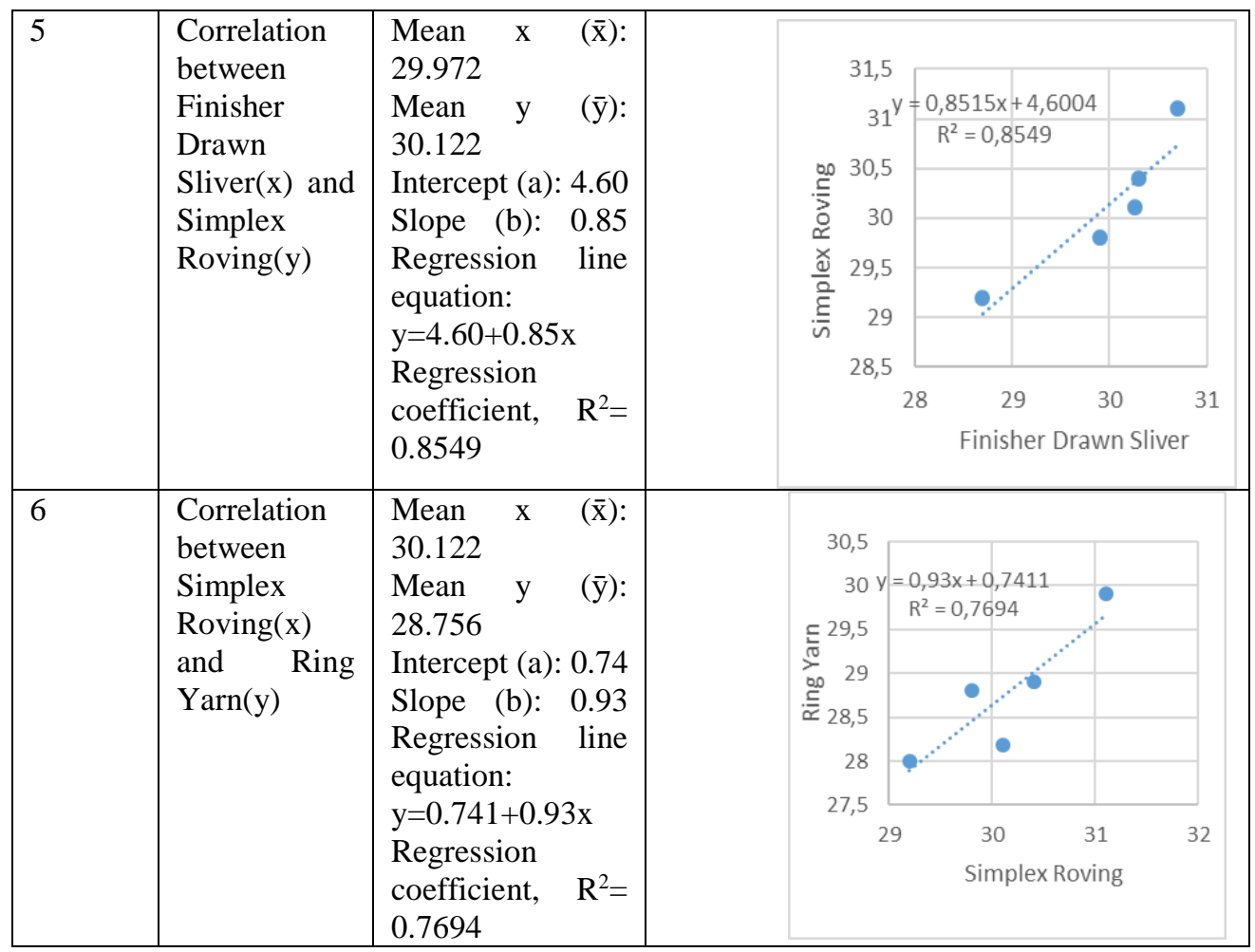

\section{Conclusion}

For all mixing types, USTER AFIS PRO length measurements revealed a general down-up-down trend. Card mat and ring fiber length dropped, however, carding, breaker drawing, finisher drawing, and simplex fiber length increased. Although an anomaly is seen for MT3 due to natural variability in raw materials, the length of the fiber was significantly reduced at the card mat stage due to beating in the blow room line, which shortened the fiber length. Because of the higher drafting force in the ring frame stage, fiber breakage was substantial, reducing the average fiber length in the ring frame. The length of fiber was significantly increased during the carding stage because carding involves the disentanglement of fiber neps and the elimination of wastes, both of which raised the average fiber length. Since drafting action removes fiber hooks in the breaker drawing, finisher drawing, and simplex machine, the average fiber length was typically increased in all three stages. Nevertheless, some anomalies were observed in the breaker draw frame (MT2), finisher draw frame (MT5), and simplex (MT2, MT4), which are caused by natural deviation in raw materials. The correlation and regression analysis exhibited a positive correlation between each stage of yarn processing and fiber, with a regression coefficient (R2) ranging from 0.5611 to 0.9509 , which will aid in anticipating changes in fiber length in due course. It will also 
facilitate the fine-tuning of machine parameters in order to produce higherquality yarn.

\section{References:}

1. Ahmad, S., Sinoimeri, A., \& Nowrouzieh, S. (2012). The effect of the sliver fiber configuration on the cotton inter-fiber frictional forces. Journal of Engineered Fibers and Fabrics, 7(2), 87-93. https://doi.org/10.1177/155892501200700213

2. Barella, A., \& Manich, A. M. (2002). Yarn hairiness: A further update. Textile Progress, 31(4), 1-44. https://doi.org/10.1080/00405160208688953

3. Bragg, C. K., \& Shofner, F. M. (1993). A Rapid, Direct Measurement of Short Fiber Content. Textile Research Journal, 63(3), 171-176. https://doi.org/10.1177/004051759306300307

4. Byatt, W. J., and Elting, J. P. (1958). in the Weight Distribution of Fiber Lengths of Cotton Result of Random. Textile Research Journal, 718(1953), 417-421.

5. Byatt, W. J. (1961). On Changes in the Weight Distribution Function of Artificial Fibers Due to Random Fiber Breakage. Textile Research Journal, 31(2), 171-174. https://doi.org/10.1177/004051756103100210

6. Cai, Y., Cui, X., Rodgers, J., Thibodeaux, D., Martin, V., Watson, M., \& Pang, su S. (2013). A comparative study of the effects of cotton fiber length parameters on modeling yarn properties. Textile Research Journal, 83(9), 961-970. https://doi.org/10.1177/0040517512468821

7. Carnaby, G. A. (1984). Fiber Breakage During Carding: Part I: Theory. Textile Research Journal, 54(6), 366-369. https://doi.org/10.1177/004051758405400602

8. Faulkner, W. B., Hequet, E. F., Wanjura, J., \& Boman, R. (2012). Relationships of cotton fiber properties to ring-spun yarn quality on selected High Plains cottons. Textile Research Journal, 82(4), 400 414. https://doi.org/10.1177/0040517511426613

9. Fiori, L. A., \& Brown, J. J. (1951). Effects of Cotton Fiber Fineness on the Physical Properties of Single Yarns. Textile Research Journal, 21(10), 750-757. https://doi.org/10.1177/004051755102101008

10. Fiori, L. A., Brown, J. J., \& Sands, J. E. (1954). Effect of Cotton Fiber Strength on Single Yarn Properties and on Processing Behavior. Textile Research Journal, 24(6), 503-507. https://doi.org/10.1177/004051755402400605

11. Fiori, L. A., Sands, J. E., Little, H. W., \& Grant, J. N. (1956). Effect of Cotton Fiber Bundle Break Elongation and Other Fiber Properties on the Properties of a Coarse and a Medium Singles Yarn. Textile 
Research Journal, 26(7), 553-564.

https://doi.org/10.1177/004051755602600710

12. Frydrych, I. (1995). Relation of Single Fiber and Bundle Strengths of Cotton. Textile Research Journal, i(1963), 513-521.

13. Goren, S. L. (1968). Distribution of lengths in the breakage of fibres or linear polymers. The Canadian Journal of Chemical Engineering, 46(3), 185-188. https://doi.org/10.1002/cjce.5450460309

14. Gregory, J. (1953). 35-Cotton yarn structure: Part v-the relation between strength measurements made on fibres, fibre bundles, yarns, and cloth. Journal of the Textile Institute Transactions, 44(11), T515T533. https://doi.org/10.1080/19447025308662614

15. Ibrahim, I. (2018). Effect of Fiber Length and Short Fiber Percent in Cotton on Fiber and Yarn Quality. Alexandria Science Exchange Journal, 39(OCTOBER-DECEMBER), 663-668.

https://doi.org/10.21608/asejaiqjsae.2018.20692

16. Informa, F., Number, W. R., House, M., Street, M., Hairiness, Y., \& Progress, T. (2009). Textile Progress (Issue May 2013).

17. Krifa, M. (2006). Fiber Length Distribution in Cotton Processing: Dominant Features and Interaction Effects. Textile Research Journal, 76(5), 426-435. https://doi.org/10.1177/0040517506062616

18. Krifa, M. (2008). Fiber Length Distribution in Cotton Processing: A Finite Mixture Distribution Model. Textile Research Journal, 78(8), 688-698. https://doi.org/10.1177/0040517508083729

19. Kuang, X., \& Yu, C. (2015). Generating cotton fiber length probability density function from fiber length parameters by finite mixture model. Journal of the Textile Institute, 106(6), 655-662.

https://doi.org/10.1080/00405000.2014.933516

20. Lee, S. W. (1968). Probability Model for Random Fiber Breakages Part II: Estimation and Application. Textile Progress, 566-576.

21. Lin, Q., Xing, M., Oxenham, W., \& Yu, C. (2012). Generation of cotton fiber length probability density function with length measures. Journal of the Textile Institute, 103(2), 225-230.

https://doi.org/10.1080/00405000.2011.566005

22. Matsuo, T. (2019). Textile Progress. Textile Progress, May 2013, 3741. https://doi.org/10.1201/9780429187766

23. Moon Won Suh. (1976). Probabilistic Assessment of Irregularity in Random Fiber Arrays-Eff ect of Fiber Length Distribution on "Variance-Length Curve. Fault Trees, April 1976, 79-96. https://doi.org/10.1002/9780470612484.ch5

24. Morais, J., James, J., Hinds, Z., Smith, W., Kelly, B., \& Hequet, E. (2020). A method to improve cotton fiber length measurement for laboratory analysis. MethodsX, 7. 
https://doi.org/10.1016/j.mex.2020.100859

25. Naylor, G. rs, Delhom, C. D., Cui, X., Gourlot, J. P., \& Rodgers, J. (2014). Understanding the influence of fiber length on the High Volume Instrument ${ }^{\mathrm{TM}}$ measurement of cotton fiber strength. Textile Research Journal, 84(9), 979-988. https://doi.org/10.1177/0040517513515318

26. Nield, R. (1953). Fibre Arrangement in Fibro Drawframe Slivers. Journal of the Textile Institute Transactions, 44(10), T479-T480. https://doi.org/10.1080/19447025308662610

27. Parsi, R. D., Kakde, M. V, Pawar, K., \& Police Patil, R. S. (2016). Influence of Fibre Length on Ring Spun Yarn Quality. International Journal of Research and Scientific Innovation, III(Viii), 2321-2705. www.rsisinternational.org

28. Pillay, K. P. R. (1964). A Study of the Hairiness of Cotton Yarns: Part II: Effect of Processing Factors. Textile Research Journal, 34(9), 783791. https://doi.org/10.1177/004051756403400908

29. RA Pittman and JD Tallant. (1990). Random-Fiber Breakage Models. Australian \& New Zealand Journal of Psychiatry, 24(3), 291-312. https://doi.org/10.3109/00048679009077697

30. Ramey, H. H., Lawson, R., \& Worley, S. (1977). Relationship of Cotton Fiber Properties to Yarn Tenacity length measurement . Specimens for the Micronaire The eight subsamples from each of the 42 original These were processed into drawing sliver on the small equipment at the ARS Cotton Spinning Laborat. Textile Research Journal, October, 685-691.

31. Robert, K. Q., \& Blanchard, L. J. (1997). Cotton Cleanability: Part I: Modeling Fiber Breakage. Textile Research Journal, 67(6), 417-427. https://doi.org/10.1177/004051759706700606

32. Robert, K. Q., Price, J. B., \& Cui, X. L. (2000). Cotton Cleanability: Part II: Effect of Simple Random Breakage on Fiber Length Distribution. Textile Research Journal, 70(2), 108-115. https://doi.org/10.1177/004051750007000204

33. Sawhney, P. S., \& Zeidman, M. (2002). Influence of Fiber Length Distribution on Strength Efficiency of Fibers in Yarn Strength Efficiency. Textile Research Journal, 72(3), 216-220.

34. Shapiro, H. N., Sparer, G., Gaffney, H. E., Armitage, R. H., \& Tallant, J. D. (1964). Mathematical Aspects of Cotton Fiber Length Distribution under Various Breakage Models. Textile Research Journal, 34(4), 303-307. https://doi.org/10.1177/004051756403400404

35. Sung Won, L. (1967). A Probability Model for Random Fiber Breakages: Part I. Theory. Textile Research Journal, 37(10), 860-874. 
https://doi.org/10.1177/004051756703701006

36. Tallant, J. D., Fiori, L. A., Alberson, D. M., \& Chapman, W. E. (1961a). The Effect of the Short Fibers in a Cotton on Its Processing Efficiency and Product Quality:Part I. Affecting the Short Fiber Content by the Addition of Cut Cotton Fibers. Textile Research Journal, 31(10), 866-872.

https://doi.org/10.1177/004051756103101004

37. Tallant, J. D., Fiori, L. A., Alberson, D. M., \& Chapman, W. E. (1961b). The Effect of the Short Fibers in a Cotton on Its Processing Efficiency and Product Quality:Part III: Pilot-Scale Processing of Yarns. Textile Research Journal, 31(10), 866-872. https://doi.org/10.1177/004051756103101004

38. Tallant, J. D., \& Landstreet, C. B. (1960). The Effect of Short Fibers in a Cotton on its Processing Efficiency and Product Quality:Part II: Yarns Made by Miniature Spinning Techniques from Differentially Ginned Cotton. Textile Research Journal, 30(10), 792-795. https://doi.org/10.1177/004051756003001008

39. Tallant, J. D., \& Pittman, R. A. (1968). Breakage Models and Measuring Techniques for Fiber. Weight-Length Distributions. Textile Research Journal, 38(2), 149-155.

https://doi.org/10.1177/004051756803800207

40. Tallant, J. D., Pittman, R. A., \& Schultz, E. F. (1966). The Changes in Fiber-Number Length Distribution Under Various Breakage Models. Textile Research Journal, 36(8), 729-737. https://doi.org/10.1177/004051756603600808

41. Viswanathan, G., Munshi, V. G., Ukidve, A. V., \& Chandran, K. (1989). A Critical Evaluation of the Relationship Between Fiber Quality Parameters and Hairiness of Cotton Yarns. Textile Research Journal, 59(11), 707-711.

https://doi.org/10.1177/004051758905901115

42. W. P. Virgin and Helmut Wakeham. (1956). Quality and Fiber Properties Part IV. The Relation Between Single Fiber Properties and the Behavior of Bundles, Slivers, and Yarns. Textile Research Journal, 177-191.

43. Wakankar, V. A., Bhaduri, S. N., Ramaswamy, B. R., \& Ghosh, G. C. (1961). Some Studies on the Formation of Hooks in Carding. Textile Research Journal, 31(11), 931-940. https://doi.org/10.1177/004051756103101103

44. Waters, W. T., Phillips, J., \& Fiori, L. A. (1966). The Effect of FiberBundle Elongation of Medium Staple Cottons on Processing Performance and Y arn Properties. Textile Research Journal, 36(11), 1004-1012. https://doi.org/10.1177/004051756603601109 
45. Yan, G., \& Yu, C. (2007). A joint influence of the distributions of fiber length and fineness on the strength efficiency of the fibers in yarn. Fibers and Polymers, 8(3), 309-312. https://doi.org/10.1007/BF02877275

46. Zurek, W., Greszta, M., Frydrych, I., \& Balcar, G. (1999). Cotton Fiber Length Changes in the Spinning Process on the Basis of AFIS Measurements. Textile Research Journal, 69(11), 804-810. https://doi.org/10.1177/004051759906901102 